\title{
DL- $\beta$-Aminobutyric Acid-Induced Resistance of Potato Against Phytophthora infestans Requires Salicylic Acid but Not Oxylipins
}

\author{
Lennart Eschen-Lippold, Simone Altmann, and Sabine Rosahl \\ Leibniz Institute of Plant Biochemistry, Weinberg 3, D-06120 Halle (Saale), Germany
}

Submitted 27 October 2009. Accepted 12 January 2010.

\begin{abstract}
Inducing systemic resistance responses in crop plants is a promising alternative way of disease management. To understand the underlying signaling events leading to induced resistance, functional analyses of plants defective in defined signaling pathway steps are required. We used potato, one of the economically most-important crop plants worldwide, to examine systemic resistance against the devastating late blight pathogen Phytophthora infestans, induced by treatment with DL- $\beta$-aminobutyric acid (BABA). Transgenic plants impaired in either the 9-lipoxygenase pathway, which produces defense-related compounds, or the 13-lipoxygenase pathway, which generates jasmonic acid-derived signals, expressed wild-type levels of BABA-induced resistance. Plants incapable of accumulating salicylic acid (SA), on the other hand, failed to mount this type of induced resistance. Consistently, treatment of these plants with the SA analog 2,6-dichloroisonicotinic acid restored BABA-induced resistance. Together, these results demonstrate the indispensability of a functional SA pathway for systemic resistance in potato induced by BABA.
\end{abstract}

New methods or agents for controlling plant diseases are of great agricultural interest due to recurring severe crop losses caused by various plant pathogens, including bacteria, viruses, oomycetes, and fungi. In the case of potato (Solanum tuberosum L.), one of the most important crop plants world wide (according to the United Nations Food and Agriculture Organization), infections with Phytophthora infestans, the causal agent of late blight disease, lead to great annual yield losses despite the intense use of protectants (Dowley et al. 2008; Fry and Goodwin 1997; Garelik 2002). To produce long-term resistance in potato, plant breeders generated cultivars harboring resistance $(R)$ genes from the wild relative Solanum demissum (Park et al. 2009; Turner 2005). According to the gene-forgene model (Flor 1971), these mediate specific recognition of those $P$. infestans races that express the corresponding avirulence proteins (Armstrong et al. 2005; Oh et al. 2009; van Poppel et al. 2008). Generally, upon R protein-induced signaling, strong defense responses are mounted, which may include an oxidative burst, defense-gene activation and local hypersen-

\section{Eschen-Lippold and S. Altmann contributed equally to the work.}

Current address for S. Altmann: Department of Disease and Stress Biology, John Innes Centre, Norwich NR4 7UH, U.K.

Corresponding author: S. Rosahl; Telephone: +49 3455582 1440; Fax: +49 3455582 1409; E-mail: srosahl@ipb-halle.de sitive cell death, leading to defeat of the attacker (Dangl and Jones 2001). Up to now, attempts to generate durable $R$ genemediated resistance in potato against $P$. infestans failed, due to the high adaptability of the pathogen (Fry 2008; Kamoun 2003). The speed of adaptation might be explained by the presence of fast-evolving families of effector proteins in highly dynamic regions of the $P$. infestans genome (Haas et al. 2009). In the last years, promising resistance genes from different wild Solanum species that confer broad-spectrum resistance against various $P$. infestans races were identified (Park et al. 2009). Introgression into domesticated potato varieties and cultivation under field conditions will test the durability of resistance mediated by these $R$ genes.

Other approaches conducted in various plant species aimed at the induction of general systemic defense responses enabling the plants to defend themselves against a broad spectrum of pathogens. These systemic defense responses have a multigenic background, making the adaptation for pathogens more difficult. They result from an initial recognition of pathogens or rhizobacteria (systemic acquired resistance [SAR] [Durrant and Dong 2004] or induced systemic resistance [ISR] [Pieterse et al. 2001], respectively) or are induced by chemical inducers. Establishment of SAR is known to be dependent on the accumulation of salicylic acid (SA) in most plants analyzed (Loake and Grant 2007). ISR of Arabidopsis, on the other hand, relies on functional jasmonic acid (JA) and ethylene (ET) signaling (Pieterse et al. 1998, 2001). Among the chemical inducers, 2,6-dichloroisonicotinic acid (INA) and benzo-(1,2,3)-thiadiazole-7-carbothioic acid $S$-methyl ester (BTH) were shown to positively act in the SAR pathway downstream of SA (Friedrich et al. 1996; Vernooij et al. 1995). Both conferred higher levels of resistance in several plant-pathogen interactions, such as INA in tobacco against Tobacco mosaic virus (TMV) (Ward et al. 1991) and BTH in wheat against Blumeria graminis f. sp. tritici (Görlach et al. 1996).

Another compound inducing systemic resistance is DL- $\beta$ aminobutyric acid (BABA). This amino-acid derivative proved to be effective in various pathosystems and different types of application (Cohen 2002; Jakab et al. 2001). The determination of the underlying regulatory signaling pathways in some systems revealed that it is not possible to generalize the requirements of specific signaling pathways for BABA-induced resistance. For example, detailed mutant analyses in Arabidopsis showed that BABA-induced resistance against Plectosphaerella cucumerina requires both functional abscissic-acid signaling and callose deposition (Ton and Mauch-Mani 2004), whereas SA signaling via functional NPR1 is indispensable for the establishment of BABA-induced resistance against Botrytis cinerea (Zimmerli et al. 2001). On the other hand, 
neither SA, JA, nor ET pathways were involved in BABAinduced resistance against the obligate biotrophic oomycete Hyaloperonospora arabidopsidis (formerly Peronospora parasitica [Zimmerli et al. 2000]).

In the potato- $P$. infestans pathosystem, BABA also induces high levels of resistance (Altamiranda et al. 2008; Cohen 2000; Si-Ammour et al. 2003). Germination of $P$. infestans is not altered on BABA-treated compared with mock-treated potato plants, but a slight reduction in appressoria formation was observed in BABA-treated plants (Kim and Jeun 2007). However, only little is known about biochemical changes during establishment of induced resistance in response to BABA treatment. Compared with mock-treated tubers, tubers pretreated with BABA and subsequently infected with $P$. infestans contained increased levels of phenols and phytoalexins as well as the defense-related proteins $\beta$-1,3-glucanase and aspartyl protease (Andreu et al. 2006; Olivieri et al. 2009). cDNA-amplification fragment length polymorphism analyses revealed the BABA- and $P$. infestans-induced accumulation of 9-lipoxygenase (9-LOX) transcripts (Li et al. 2009).

Since these correlative data do not reveal a role of specific compounds for BABA-induced resistance in potato, we addressed this point by performing functional analyses. Transgenic potato plants with reduced levels of SA (Halim et al. 2004) and JA (Halim et al. 2009) as well as 9-LOX-derived oxylipins (Eschen-Lippold et al. 2007; Göbel et al. 2003) were analyzed to assess the role of these compounds in mediating or establishing BABA-induced resistance. 9-LOX-derived oxylipins were included, based on the observation from other pathosystems that these oxylipins i) have functions in establishing resistance (Cowley and Walters 2005; Gao et al. 2008, 2009; Rancé et al. 1998), ii) have direct antimicrobial effects (Prost et al. 2005; Weber et al. 1999), or iii) are needed by the attacking pathogen for differentiation and virulence (Gao et al. 2007; Isakeit et al. 2007; Sagaram et al. 2006). Potato plants unable to accumulate SA but not those with reduced levels of JA or 9-LOX-derived oxylipins were compromised in establishing BABA-induced resistance. Since this defect is rescued by exogenous application of the SA analog INA, it can be concluded that the ability to accumulate SA is required for BABA-induced resistance in potato.

\section{RESULTS}

Effects of BABA on infections with $P$. infestans.

To establish reproducible conditions for infection experiments after BABA pretreatment, potato wild-type plants were soildrenched with different concentrations of BABA prior to inoculation with $P$. infestans. Subsequent pathogen biomass determinations were carried out with a realtime polymerase chain reaction (PCR)-based approach by quantifying $P$. infestans DNA (data not shown). Applications of $1 \mathrm{mM}$ BABA proved to induce a resistance state strongly inhibiting $P$. infestans growth compared with that found in mock-treated plants (Fig. 1A). Under these experimental conditions, the expression of the defense-related genes StPR1, StPR5 (pathogenesis-related 1 and 5), and St4CL (4-coumarate:CoA ligase) as well as StPIN2 (proteinase-inhibitor 2) as a JA-dependent gene was analyzed by Northern hybridizations and was compared with mocktreated plants (Fig. 1B). Transcripts of all genes analyzed accumulated in $P$. infestans-treated leaves. Higher transcript levels of StPRI and StPR5 were detectable 1 day after infection, while expression of St4CL and StPIN2 occurred after 2 and 3 days, respectively. Interestingly, none of the genes tested showed stronger expression in samples derived from BABAtreated plants compared with samples from mock-treated plants. Indeed, despite the elevated resistance after BABA treatment, the defense-related marker genes showed less expression in these plants. This is in contrast to other plants in which BABA treatment can induce a 'primed' state of the plant that results in faster and stronger defense-gene expression after pathogen infection in BABA-treated plants compared with that in untreated plants (Cohen 2002). Possibly, the lower levels of $P R$ gene expression in BABA-treated potato plants result from the reduced pathogen spread, which leads to a lower number of infected and, thus, responding cells.

To show that StPRI and StPR5 expression in potato is dependent on the SA pathway, plants were sprayed with SA or its analog, INA. RNA analyses revealed SA- and INA-dependent accumulation of StPRI and StPR5 transcripts (Fig. 1C). Thus, both SA- and JA-inducible genes are activated upon $P$. infestans infection in both untreated and BABA-treated plants. Interestingly, BABA treatment of potato plants did not induce the accumulation of JA, JA-Ile, nor its biosynthetic precursor 12-oxo-phytodienoic acid (OPDA) (Fig. 1D). Moreover, no significant differences in SA or SA glucoside (SAG) levels for up to $48 \mathrm{~h}$ were observed after BABA-treatment (Fig. 1D).

\section{The role of the 9-LOX pathway \\ in BABA-induced resistance.}

For 9- and 13-LOX pathway-generated oxylipins, defenserelated functions have been described either as signaling or direct antimicrobial compounds (Rosahl and Feussner 2004; Wasternack 2007). To analyze whether BABA treatment had an effect on the expression of these oxylipin biosynthetic genes, their transcript levels were determined in plants after BABA-treatment alone or after subsequent $P$. infestans inoculation. Under the experimental conditions, BABA alone did not induce transcript accumulation of the 9-LOX branch genes encoding 9-LOX (StLOXI) and 9-divinyl ether synthase (St9DES) (Fig. 2A). Following infection with P. infestans, transcripts of both genes accumulated in plants with or without pretreatment with BABA. As seen for the defense-related genes in Figure 1B, expression was higher in infected plants without BABA treatment, which became evident especially in case of St9DES (Fig. 2B). Transgenic plants expressing RNAinterference constructs against StLOXI (Göbel et al. 2003) and the downstream St9DES (Eschen-Lippold et al. 2007) were subsequently tested for their ability to mount BABA-induced resistance. We already reported that, without any additional treatments, St9DES-RNAi plants display the same level of susceptibility towards $P$. infestans as control plants (EschenLippold et al. 2007). Here, we demonstrate also that, in untreated StLOX1-RNAi plants, growth of $P$. infestans is equal to that in control plants (Fig. 2C). Together, these results indicate that the entire 9-LOX branch of the oxylipin pathway is dispensable for basal resistance in this interaction. Interestingly, pretreatment of StLOX1-RNAi and St9DES-RNAi plants with BABA induced resistance against $P$. infestans to the same extent of control plants (Fig. 2C). Therefore, 9-LOX pathwayderived antimicrobial compounds are also dispensable for BABA-induced resistance in this interaction.

\section{The role of the 13-LOX pathway \\ in BABA-induced resistance.}

Treatment of potato wild-type plants with BABA did not induce transcript accumulation of the 13-LOX branch genes StLOX3, StAOC (allene oxide cyclase), and StOPR3 (12OPDA-reductase 3). For StOPR3, no basal transcript levels could be detected, while for the two upstream genes StLOX3 and $S t A O C$, certain levels of basal expression were present (Fig. 3A). These varied slightly at the different timepoints but were not reproducibly elevated by BABA in different experiments. In accordance with this lack of induced expression, 
A

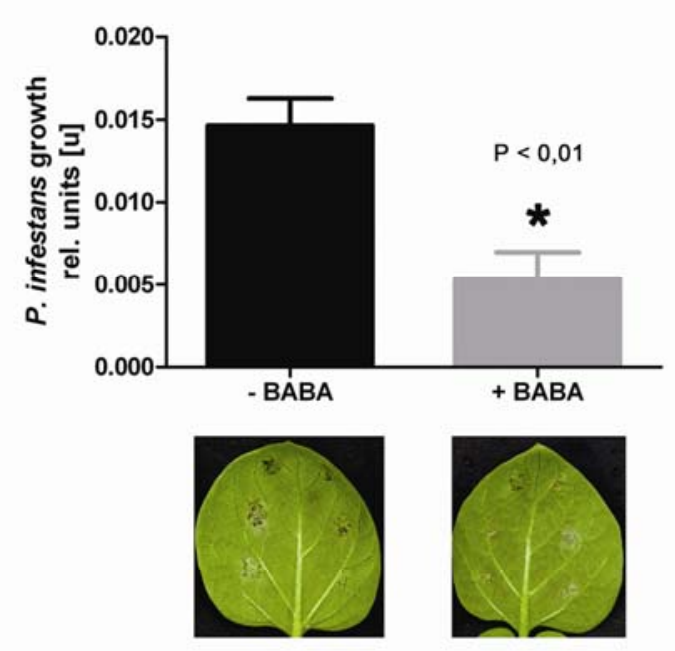

B
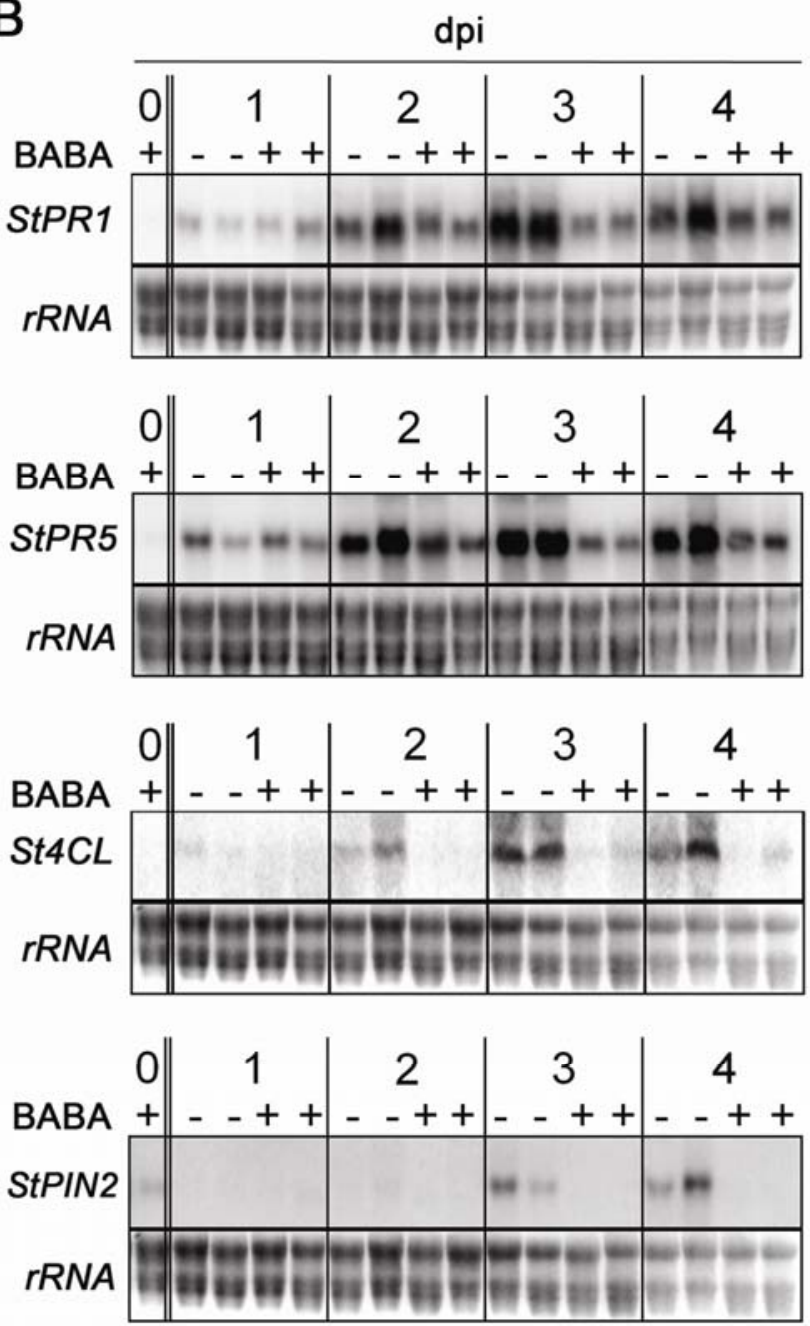
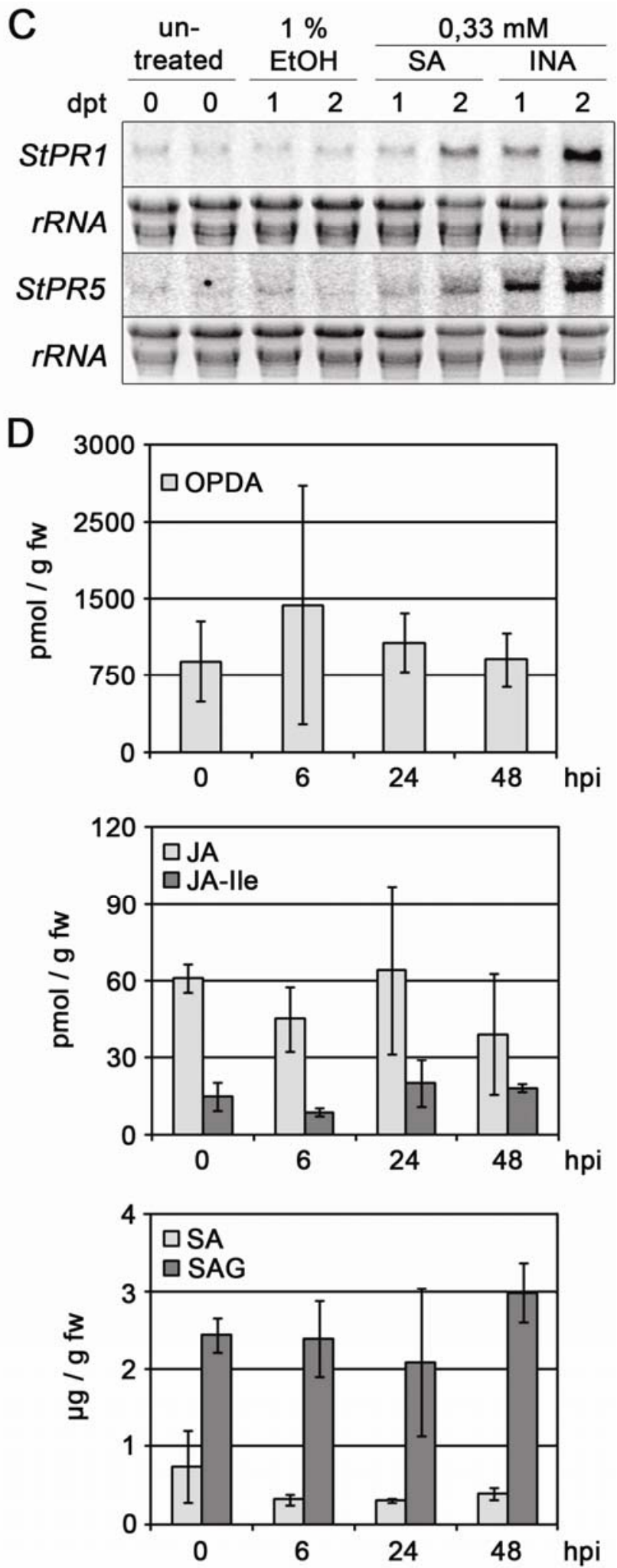

Fig. 1. DL- $\beta$-aminobutyric acid (BABA)-induced resistance against Phytophthora infestans in wild-type potato plants. A, Untreated potato control plants and plants pretreated with BABA were inoculated with $P$. infestans. Samples for $P$. infestans biomass determinations were harvested 3 days later and were analyzed by quantitative real time polymerase chain reaction. Plants pretreated with BABA were significantly more resistant $($ Mann-Whitney test, $P<0.01)$. B, RNA was isolated from leaves of untreated or BABA-treated plants after infection with $P$. infestans at the timepoints indicated. Northern-hybridizations were carried out with radioactively labeled probes of defense-related genes StPR1, StPR5, St4CL, and StPIN2. rRNA was stained with ethidium bromide to visualize equal loading. C, RNA was isolated from leaves of untreated plants or plants treated with ethanol (EtOH), SA, or 2,6-dichloroisonicotinic acid (INA) for 1 or 2 days. Northern analyses were carried out using radioactively labeled probes of StPR1 and StPR5. rRNA was stained with ethidium bromide to visualize equal loading. D, Levels of 12-oxo-phytodienoic acid (OPDA), JA, JA-Ile, SA, and SA glucoside (SAG) were determined in leaves of BABA-treated plants at the timepoints indicated. 
measurements of OPDA, JA, and JA-Ile did not reveal any changes in overall contents (Fig. 1 D).

Upon infection with $P$. infestans, transcripts of StLOX3 accumulated 3 to 4 days postinoculation. This result was seen in both BABA-treated and untreated control plants, occurring to the same extent (Fig. 3B). For StAOC and StOPR3, no increase of the constitutive transcript levels was found upon $P$. infestans infection (Fig. 3B). To assess the influence of the 13-LOX branch on establishing BABA-induced resistance in potato, plants impaired in JA biosynthesis (StAOC-RNAi and StOPR3RNAi) and JA perception (StCOII-RNAi) (Halim et al. 2009) were analyzed. Interestingly, watering the plants with BABA induced the same level of resistance against $P$. infestans in transgenic RNAi-silenced plants and control plants (Fig. 3C), proving the JA-independence of BABA-induced resistance in the potato- $P$. infestans pathosystem.

\section{The role of $\mathrm{SA}$ in $\mathrm{BABA}$-induced resistance.}

In previous work, we demonstrated the importance of SA for basal resistance of potato against $P$. infestans (Halim et al. 2007, 2009). In this study, we used transgenic plants expressing a bacterial salicylate hydroxylase gene (NahG), which converts SA to catechol (Gaffney et al. 1993). These plants are impaired in SA accumulation and were used to determine the impact of SA on BABA-induced resistance against $P$. infestans. In the first place, experiments with potato wild-type plants revealed that BABA-treatment does not induce the accumulation of SA or SAG (Fig. 1 D). In infection experiments with $P$. infestans, BABA-treated wild-type plants macroscopically developed smaller lesions than untreated plants. NahG plants, however, did not show any treatment-dependent differences in lesion formation (Fig. 4A). Strikingly, P. infestans biomass determinations revealed that $N a h G$ plants were not able to mount BABA-induced resistance to a significant extent (Fig. 4B). As previously published, NahG-expressing plants allowed significantly elevated colonization by $P$. infestans compared with that in control plants, despite no significant differences in lesion size (Fig. 4A and B) (Halim et al. 2007).

Defects of NahG potato plants can be rescued by the exogenous application of the SA analog INA, which, by itself, does not influence growth of $P$. infestans on potato plants (Halim et al. 2007, 2009). Spraying NahG plants with $0.33 \mathrm{mM}$ INA restored BABA-induced resistance to levels observed in BABAtreated wild-type plants (Fig. 4B). Thus, our results suggest that the ability to accumulate SA is essential for this type of chemically induced resistance against $P$. infestans in potato.

\section{DISCUSSION}

In the context of an increasing requirement for food security, the importance of potato as one of the five major crop plants world wide and the devastating crop losses due to $P$. infestans infection have prompted research into alternative ways to manage disease. In potato, resistance against $P$. infestans can be induced by infection with pathogens (Kombrink et al. 1996) and by exogenous application of compounds such as JA, arachidonic acid, or BABA (Cohen 2002; Cohen et al. 1993; Coquoz et al. 1995).

Since the mechanisms of BABA-induced resistance in potato are not understood, we analyzed the role of the 9-LOX pathway as well as the signaling compounds JA and SA for resistance in potato, using transgenic plants with reduced amounts of these compounds.

The rationale to analyze the role of 9-LOX-derived oxylipins for BABA-induced resistance was based on the observation that these compounds accumulate in potato plants in response to infection with $P$. infestans or Pseudomonas syringae pv. maculicola (Göbel et al. 2002). Data from other pathosystems, for instance almond-Aspergillus carbonarius (Mita et al. 2007) or cotton-Xanthomonas campestris (Marmey et al. 2007), also
A
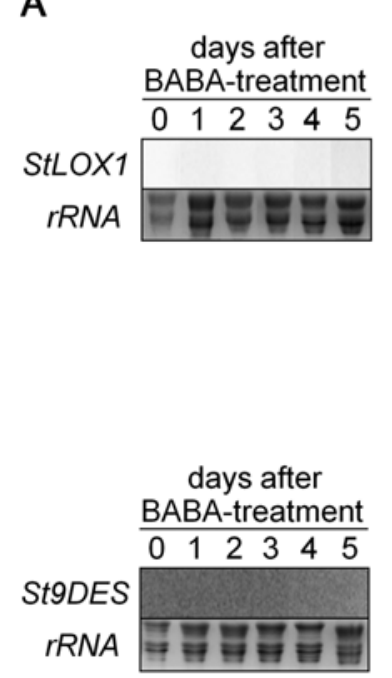
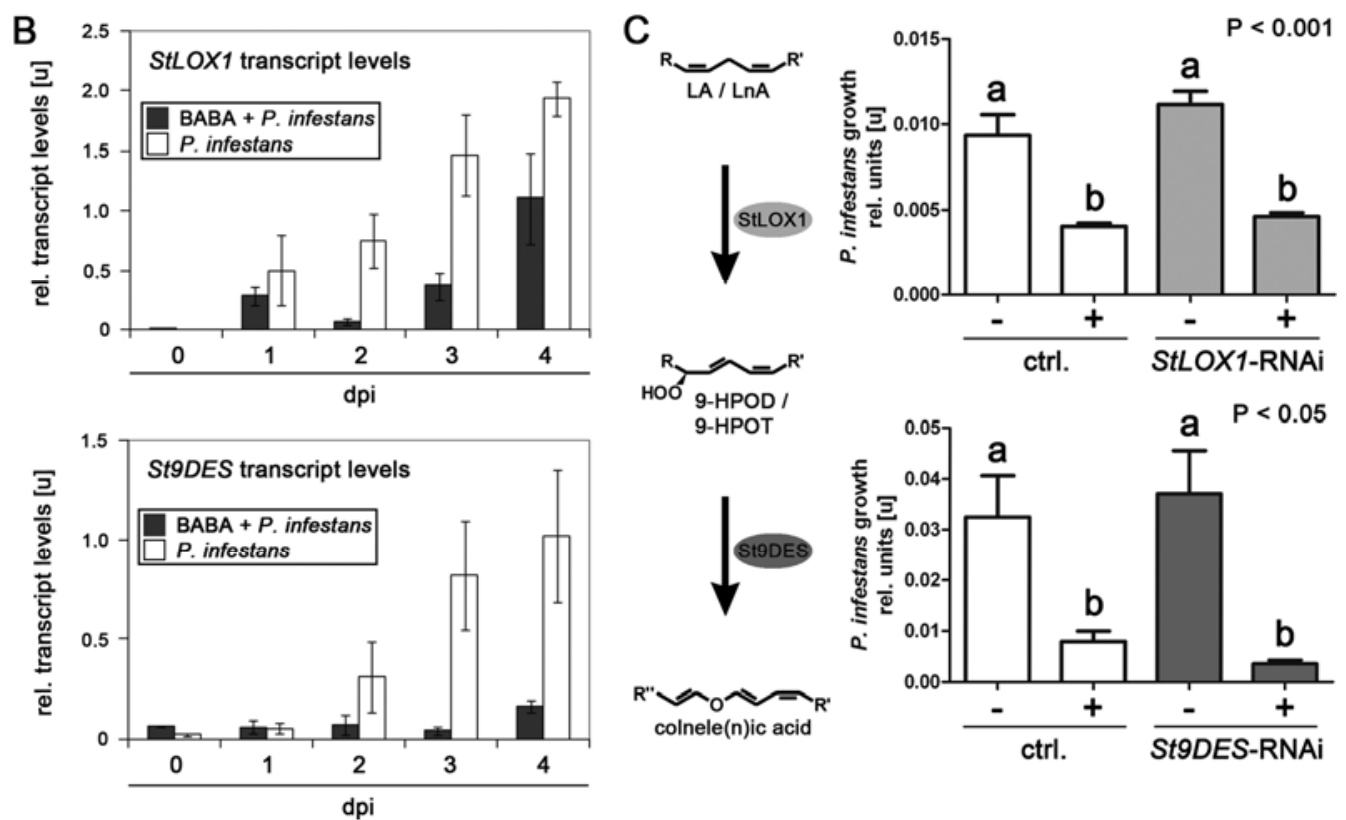
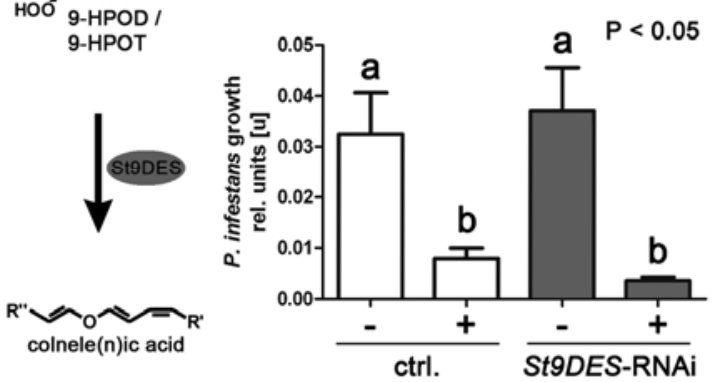

Fig. 2. The role of the 9-lipoxygenase (9-LOX) pathway for DL- $\beta$-aminobutyric acid (BABA)-induced resistance. A, RNA from leaves of wild-type potato plants treated with BABA was subjected to Northern analyses. Hybridization was carried out with radioactively labeled probes of StLOX1 and St9DES. rRNA was stained with ethidium bromide to visualize equal loading. B, RNA was isolated from leaves of untreated or BABA-treated plants after infection with Phytophthora infestans at the timepoints indicated (dpi = days postinfection). Northern hybridizations were carried out with radioactively labeled probes of StLOX1 and St9DES. The graphs show signal intensities calculated from three independent experiments. C, Control plants (ctrl. = wild-type and empty vector-containing plants) as well as transgenic plants expressing RNAi constructs against StLOX1 and St9DES were inoculated with $P$. infestans. Pathogen biomass was determined by quantitative real time polymerase chain reaction 3 days after infection (with [+] and without [-] BABA pretreatment). Different letters indicate statistically significant differences (Kruskal-Wallis test, $P$ values as indicated). 
point to an involvement of the 9-LOX pathway in pathogen defense. Moreover, a crucial role for the pathogen-induced 9LOX of tobacco was demonstrated for race-cultivar-specific resistance against Phytophthora parasitica (Rancé et al. 1998). In maize, 9-LOX is required for defense against root knot nematodes (Gao et al. 2008). Finally, a possible role of 9-LOX products for systemic signaling was suggested. Lipid transfer proteins such as DIR1 (Maldonado et al. 2002) or AZI1 (Jung et al. 2009) are important for systemic signaling in Arabidopsis; however, the nature of the lipid bound by these proteins has not been elucidated. In barley seeds, a lipid transfer protein (LTP) is covalently modified by the $\alpha$-ketol 9-hydroxy10-oxo-12(Z)-octadecenoic acid, a product of the 9-LOX and 9-allene oxide synthase (AOS) branch of the LOX pathway (Bakan et al. 2006). This result, together with the determination of the LTP-oxylipin conjugate's crystal structure (Bakan et al. 2009), allows speculation about a possible role of 9-LOX products in systemic signaling. The compromised accumulation of 9-LOX-derived oxylipins in StLOX1-RNAi and St9DESRNAi potato plants (Eschen-Lippold et al. 2007; Göbel et al. 2003), therefore, presented a suitable system to evaluate possible signaling functions of 9-LOX-derived oxylipins. However, BABA-induced resistance was not altered in plants with downregulated 9-LOX-pathway genes (Fig. 2C), demonstrating that these compounds do not play a role or are dispensable for BABA-induced resistance in potato.

As for 9-LOX-derived oxylipins, the inability of potato plants to synthesize or perceive JA is not relevant for the induction of resistance against $P$. infestans by BABA (Fig. 3C).
Similarly, JA synthesis or signaling was not required for protection of Arabidopsis plants by BABA against $H$. arabidopsidis or P. syringae pv. tomato DC3000 (Zimmerli et al. 2000). In addition, the Arabidopsis coil mutant still exhibits BABAinduced resistance against the necrotrophic fungi Alternaria brassicicola and Plectosphaerella cucumerina (Ton and MauchMani 2004). Inhibitor studies in grapevine, on the other hand, point to an involvement of the JA pathway in BABA-induced resistance against Plasmopara viticola (Hamiduzzaman et al. 2005). Also, the tomato def mutant, which has an unknown defect in JA accumulation (Howe et al. 1996), does not mount resistance against $P$. infestans upon BABA treatment, as determined by evaluation of disease symptoms (Yan et al. 2002). These studies nicely emphasize that the requirement of specific signaling compounds for BABA-induced resistance, such as JA, depend on both plant and pathogen species.

In contrast to 9-LOX-derived oxylipins and JA, SA is indispensable for the establishment of BABA-induced resistance in potato against $P$. infestans (Fig. 4). Concerning the induction of SA accumulation, different types of BABA application were analyzed in other solanaceous species. Spraying BABA induced transient increases of SA levels in leaves of tobacco (Siegrist et al. 2000) and pepper (Hwang et al. 1997), whereas in tomato, $1 \mathrm{mM}$ BABA applied as soil-drench did not induce SA accumulation in aboveground parts (Jeun et al. 2000). Similarly, our own results from potato plants watered with 1 mM BABA did not reveal SA accumulation in leaves (Fig. 1D). In another study from tomato, watering with 10-fold higher concentrations of BABA $(10 \mathrm{mM})$ led to a transient SA
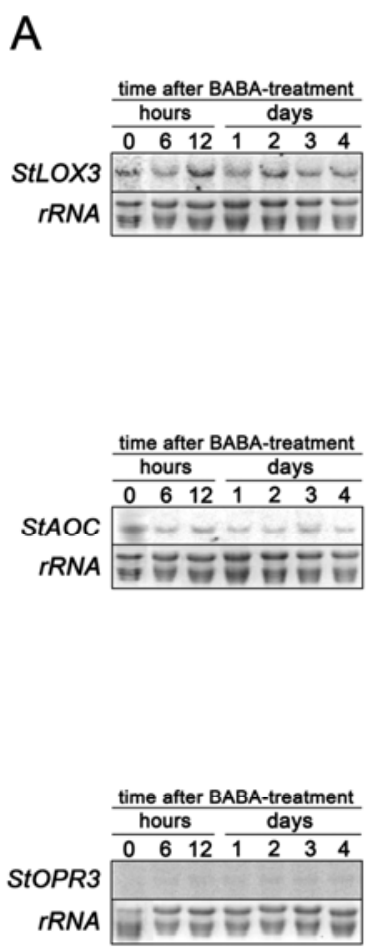

B
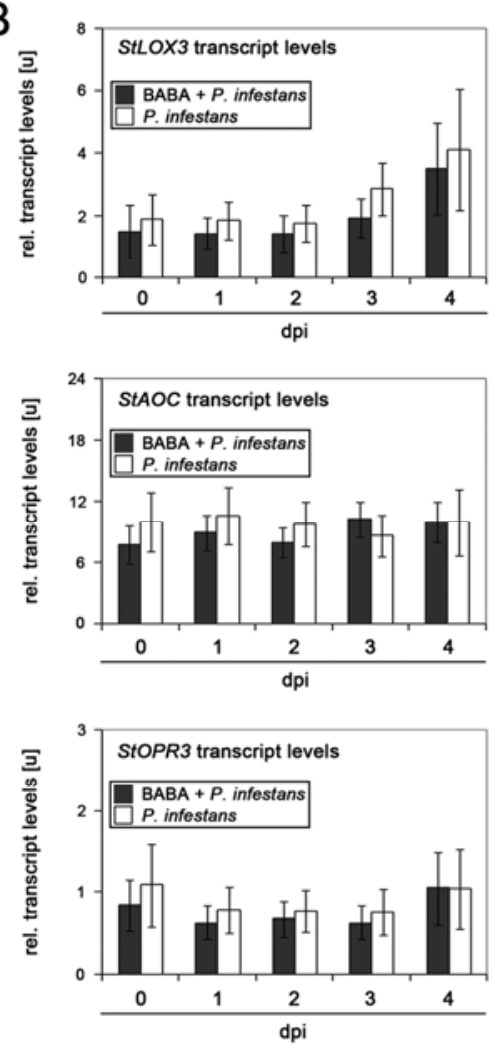
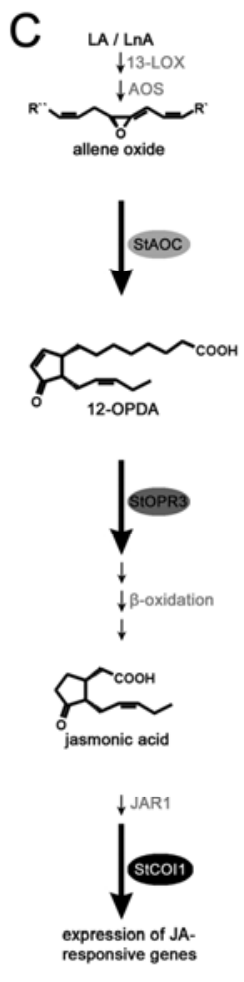
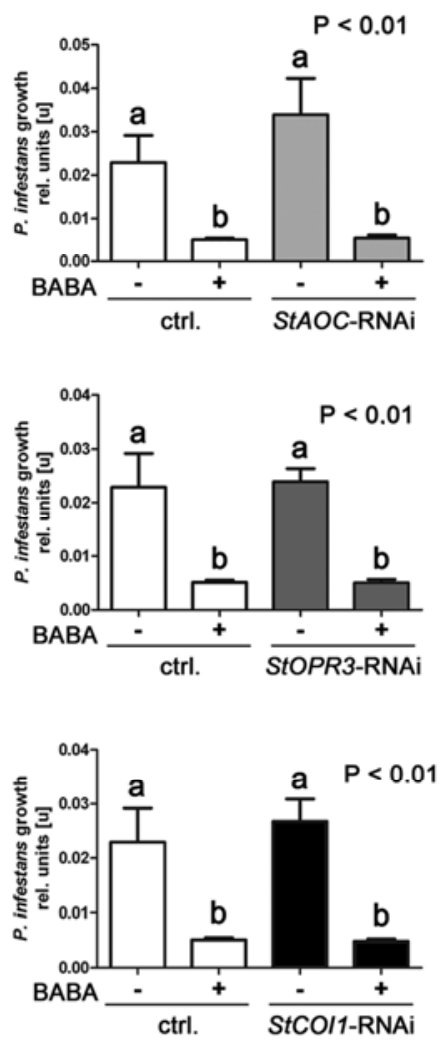

Fig. 3. The role of the 13- lipoxygenase (13-LOX) pathway for DL- $\beta$-aminobutyric acid (BABA)-induced resistance. A, RNA from leaves of wild-type potato plants treated with BABA was subjected to Northern analyses. Hybridization was carried out with radioactively labeled probes of StLOX3, StAOC, and StOPR3. rRNA was stained with ethidium bromide to visualize equal loading. B, RNA was isolated from leaves of untreated (white bars) or BABA-treated plants (black bars) after infection with Phytophthora infestans at the timepoints indicated (dpi = days postinfection). Northern hybridizations were carried out with radioactively labeled probes of $S t L O X 3, S t A O C$, and $S t O P R 3$. The graphs show signal intensities calculated from two independent experiments. C, Control plants (ctrl. = wild-type and empty vector-containing plants) as well as transgenic plants expressing RNAi constructs against $S t L O X 3$, StAOC, and StOPR3 were inoculated with $P$. infestans. Pathogen biomass was determined by quantitative real time polymerase chain reaction 3 days after infection (with $[+]$ or without $[-]$ BABA pretreatment). Different letters indicate statistically significant differences (Kruskal-Wallis test, $P$ values as indicated). 
accumulation in roots correlating with cell death, pointing to an overload of the experimental system (Chamsai et al. 2004). The same effect was seen in our own experiments, leading even to death of the plants one day after watering with very high concentrations of BABA (1 M; data not shown).

In previous work, we demonstrated that SA is necessary for basal resistance of potato against $P$. infestans (Halim et al. 2007). In this study, our finding that $N a h G$-expressing potato plants are unable to mount BABA-induced resistance, clearly demonstrates the crucial involvement of SA also in this type of chemically induced resistance against $P$. infestans (Fig. 4B). The SA analog INA, which itself does not inhibit $P$. infestans growth on wild-type plants (Halim et al. 2007), restored the ability to establish BABA-induced resistance in NahG potato lines (Fig. 4B). This corroborates our finding that INA also complements basal resistance against $P$. infestans in these plants (Halim et al. 2007). Studies of BABA-induced resistance in other solanaceous species showed the involvement of SA in the tomato-P. infestans (Yan et al. 2002) and tobaccoTMV (Siegrist et al. 2000) pathosystems. In contrast, in Arabidopsis, BABA-induced resistance against $P$. cucumerina was unaffected both in NahG-expressing plants and the SA signaling mutant nprl (Ton and Mauch-Mani 2004).

So far, no detailed analyses with potato plants impaired in the accumulation and perception of signaling pathway components had been conducted. Thus, our results contribute to the understanding of chemically induced resistance in the important potato- $P$. infestans pathosystem. BABA may serve as an

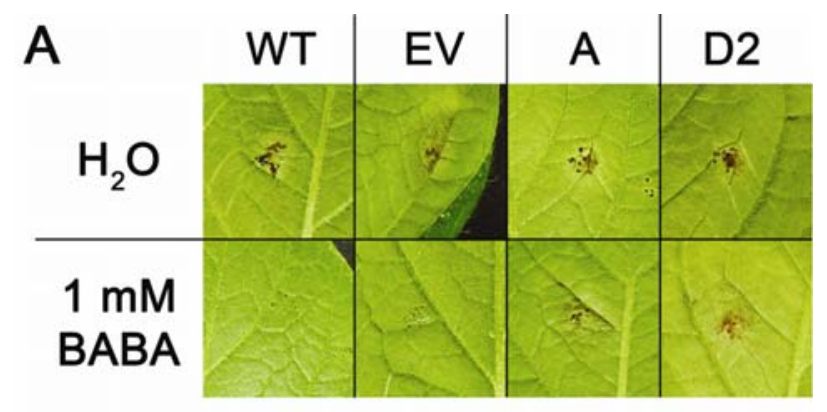

B

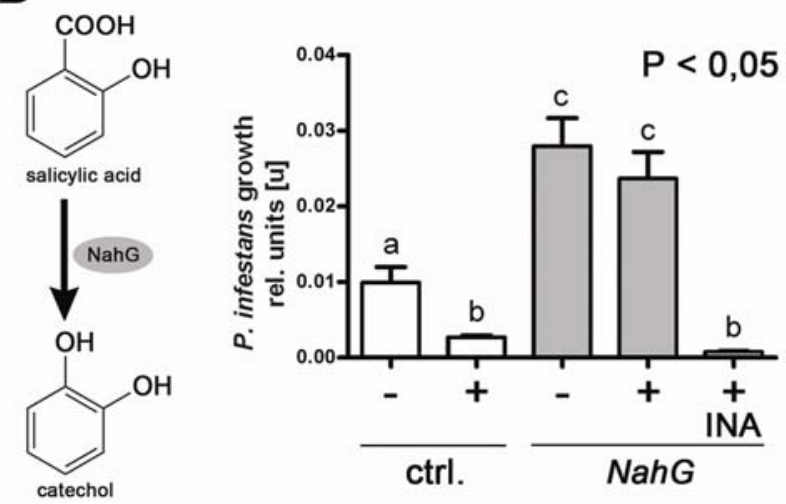

Fig. 4. The role of salicylic acid (SA) for DL- $\beta$-aminobutyric acid (BABA)induced resistance. A, Untreated $\left(\mathrm{H}_{2} \mathrm{O}\right)$ or BABA-treated (1 mM BABA) wild-type (WT) potato plants as well as transgenic plants containing the empty vector (EV) or the NahG gene (A and D2) were infected with Phytophthora infestans. Representative inoculation sites 3 days after infection are shown. B, Control plants (ctrl. = wild-type and empty vector-containing plants) as well as transgenic $N a h G$ plants were inoculated with $P$. infestans. In addition, BABA-treated $N a h G$ plants were sprayed with 2,6-dichloroisonicotinic acid (INA) prior to infection with $P$. infestans. Pathogen biomass was determined by quantitative real time polymerase chain reaction 3 days after infection (with $[+]$ or without $[-]$ BABA pretreatment). Different letters indicate statistically significant differences (Kruskal-Wallis test, $P<0.05$ ). inducer of resistance with great potential for potato cultivation, since it is transported in potato plants upon leaf treatment (Cohen 2002) and applications throughout the crop cycle increase tuber yield (Olivieri et al. 2009) and resistance against $P$. infestans in stored tubers (Andreu et al. 2006).

\section{MATERIALS AND METHODS}

\section{Cultivation and treatment of plants.}

In this study, potato wild-type plants ( $S$. tuberosum cv. Désirée) were used as well as transgenic Désirée plants harboring RNA-interference constructs targeted against genes of the LOX pathway, StLOX1-RNAi (Göbel et al. 2003), St9DESRNAi (Eschen-Lippold et al. 2007), StAOC-RNAi, StOPR3RNAi, and StCOI1-RNAi (Halim et al. 2009). To target the SA pathway, Désirée plants expressing a salicylate hydroxylase (NahG plants) were used (Halim et al. 2004). Potato plants were grown as described by Halim and associates (2007), and infection experiments with $P$. infestans were carried out in a phytochamber as previously described (Eschen-Lippold et al. 2009). BABA (Sigma-Aldrich, St. Louis) was applied by watering the plants with $100 \mathrm{ml}$ BABA $(1 \mathrm{mM}$, dissolved in water) 2 days prior to inoculation with $P$. infestans. To rescue the SA-deficient phenotype of $N a h G$ plants, $0.33 \mathrm{mM}$ INA (Sigma-Aldrich) in $1 \%$ ethanol or $1 \%$ ethanol alone was sprayed on the adaxial leaf surface of the plants 1 day prior to $P$. infestans inoculation on the abaxial side of the leaf.

\section{RNA analyses.}

Northern analyses were performed with radioactively labeled cDNA probes from StLOX1 (Geerts et al. 1994), St9DES (Göbel et al. 2001), StLOX3 (Royo et al. 1996), StAOC (Halim et al. 2009), StOPR3 (Halim et al. 2009), StPIN2 (X04118), St4CL (Becker-André et al. 1991), StPRl (TC126356), and StPR5 (TC112036). Experimental conditions were previously described (Halim et al. 2004). To calculate relative expression data, signal intensities were standardized to ethidium bromidestained rRNA.

\section{Determination of SA and JA.}

To extract SA and SAG, the method of Verberne and associates (2002) was applied by either using a high-performance liquid chromatography system (Halim et al. 2004) or an Acquity UPLC $(\mathrm{BEH}$ C18 $1.7 \mu \mathrm{m} 2.1 \times 50 \mathrm{~mm}$ column; Waters Corp., Milford, MA, U.S.A.). Details about the extraction are given by Halim and associates (2004). SA was detected using an excitation wavelength of $300 \mathrm{~nm}$ and an emission wavelength of $410 \mathrm{~nm}$. JA was measured according to Göbel and associates (2002).

\section{Determination of $P$. infestans biomass.}

Pathogen biomass was determined by real time PCR as described (Eschen-Lippold et al. 2007).

\section{Statistical analyses.}

Statistical data analyses were carried out using the software Prism 5 (GraphPad Software, Inc., La Jolla, CA, U.S.A.).

\section{ACKNOWLEDGMENTS}

We thank U. Smolka for excellent technical assistance. This work was supported by the Deutsche Forschungsgemeinschaft (SFB 648, TPA4).

\section{LITERATURE CITED}

Altamiranda, E. A. G., Andreu, A. B., Daleo, G. R., and Olivieri, F. P. 2008. Effect of beta-aminobutyric acid (BABA) on protection against 
Phytophthora infestans throughout the potato crop cycle. Austral. Plant Pathol. 37:421-427.

Andreu, A. B., Guevara, M. G., Wolski, E. A., Daleo, G. R., and Caldiz, D. O. 2006. Enhancement of natural disease resistance in potatoes by chemicals. Pest Manag. Sci. 62:162-170.

Armstrong, M. R., Whisson, S. C., Pritchard, L., Bos, J. I., Venter, E., Avrova, A. O., Rehmany, A. P., Böhme, U., Brooks, K., Cherevach, I., Hamlin, N., White, B., Fraser, A., Lord, A., Quail, M. A., Churcher, C., Hall, N., Berriman, M., Huang, S., Kamoun, S., Beynon, J. L., and Birch, P. R. 2005. An ancestral oomycete locus contains late blight avirulence gene Avr3a, encoding a protein that is recognized in the host cytoplasm. Proc. Natl. Acad. Sci. U.S.A.102:7766-7771.

Bakan, B., Hamberg, M., Perrocheau, L., Maume, D., Rogniaux, H., Tranquet, O., Rondeau, C., Blein, J.P., Ponchet, M., and Marion, D. 2006. Specific adduction of plant lipid transfer protein by an allene oxide generated by 9-lipoxygenase and allene oxide synthase. J. Biol. Chem. 281:38981-38988.

Bakan, B., Hamberg, M., Larue, V., Prangé, T., Marion, D., and Lascombe, M. B. 2009. The crystal structure of oxylipin-conjugated barley LTP1 highlights the unique plasticity of the hydrophobic cavity of these plant lipid-binding proteins. Biochem. Biophys. Res. Commun. 390:780-785.

Becker-André, M., Schulze-Lefert, P., and Hahlbrock, K. 1991. Structural comparison, modes of expression, and putative cis-acting elements of the two 4-coumarate: CoA ligase genes in potato. J. Biol. Chem. 266:8551-8559.

Chamsai, J., Siegrist, J., and Buchenauer, H. 2004. Mode of action of the resistance-inducing 3-aminobutyric acid in tomato roots against Fusarium wilt. Z. Pflanzenk. Pflanzens.-J. Plant Dis. Prot. 111:273-291.

Cohen, Y. 2000. Methods for protecting plants from fungal infection. U.S. Patent 6075051. June.

Cohen, Y. R. 2002. beta-aminobutyric acid-induced resistance against plant pathogens. Plant Dis. 86:448-457.

Cohen, Y., Gisi, U., and Niderman, T. 1993. Local and systemic protection against Phytophthora infestans induced in potato and tomato plants by jasmonic acid and jasmonic methyl-ester. Phytopathology 83:1054-1062.

Coquoz, J. L., Buchala, A. J., Meuwly, P., and Métraux, J. P. 1995. Arachidonic-acid induces local but not systemic synthesis of salicylic-acid and confers systemic resistance in potato plants to Phytophthora infestans and Alternaria solani. Phytopathology 85:1219-1224.

Cowley, T., and Walters, D. 2005. Local and systemic effects of oxylipins on powdery mildew infection in barley. Pest Manag. Sci. 61:572-576.

Dangl, J. L., and Jones, J. D. 2001. Plant pathogens and integrated defence responses to infection. Nature 411:826-833.

Dowley, L. J., Grant, J., and Griffin, D. 2008. Yield losses caused by late blight (Phytophthora infestans (Mont.) de Bary) in potato crops in Ireland. Irish J. Agr. Food Res. 47:69-78.

Durrant, W. E., and Dong, X. 2004. Systemic acquired resistance. Annu. Rev. Phytopathol. 42:185-209.

Eschen-Lippold, L., Rothe, G., Stumpe, M., Göbel, C., Feussner, I., and Rosahl, S. 2007. Reduction of divinyl ether-containing polyunsaturated fatty acids in transgenic potato plants. Phytochemistry 68:797-801.

Eschen-Lippold, L., Draeger, T., Teichert, A., Wessjohann, L., Westermann, B., Rosahl, S., and Arnold, N. 2009. Antioomycete activity of gammaoxocrotonate fatty acids against $P$. infestans. J. Agric. Food Chem. 57: 9607-9612.

Flor, H. H. 1971. Current status of the gene-for-gene concept. Annu. Rev. Phytopathol. 9:275-296.

Friedrich, L., Lawton, K., Ruess, W., Masner, P., Specker, N., Rella, M. G., Meier, B., Dincher, S., Staub, T., Uknes, S., Métraux, J. P., Kessmann, H., and Ryals, J. 1996. A benzothiadiazole derivative induces systemic acquired resistance in tobacco. Plant J. 10:61-70.

Fry, W. 2008. Phytophthora infestans: The plant (and $R$ gene) destroyer. Mol. Plant Pathol. 9:385-402.

Fry, W. E., and Goodwin, S. B. 1997. Resurgence of the Irish potato famine fungus. Bioscience 47:363-371.

Gaffney, T., Friedrich, L., Vernooij, B., Negrotto, D., Gordon, N., Uknes, S., Ward, E., Kessmann, H., and Ryals, J. 1993. Requirement of salicylic acid for the induction of systemic acquired resistance. Science 261:754-756

Gao, X. Q., Shim, W.-B., Göbel, C., Kunze, S., Feussner, I., Meeley, R., Balint-Kurti, P., and Kolomiets, M. 2007. Disruption of a maize 9-lipoxygenase results in increased resistance to fungal pathogens and reduced levels of contamination with mycotoxin fumonisin. Mol. PlantMicrobe Interact. 20:922-933.

Gao, X. Q., Starr, J., Göbel, C., Engelberth, J., Feussner, I., Tumlinson, J., and Kolomiets, M. 2008. Maize 9-lipoxygenase ZmLOX3 controls development, root-specific expression of defense genes, and resistance to root-knot nematodes. Mol. Plant-Microbe Interact. 21:98-109.

Gao, X., Brodhagen, M., Isakeit, T., Brown, S. H., Göbel, C., Betran, J., Feussner, I., Keller, N. P., and Kolomiets, M. V. 2009. Inactivation of the lipoxygenase $Z m L O X 3$ increases susceptibility of maize to Aspergillus spp. Mol. Plant-Microbe Interact. 22:222-231.

Garelik, G. 2002. Agriculture. Taking the bite out of potato blight. Science 298:1702-1704.

Geerts, A., Feltkamp, D., and Rosahl, S. 1994. Expression of Lipoxygenase in wounded tubers of Solanum tuberosum L. Plant Physiol. 105:269-277

Göbel, C., Feussner, I., Schmidt, A., Scheel, D., Sanchez-Serrano, J., Hamberg, M., and Rosahl, S. 2001. Oxylipin profiling reveals the preferential stimulation of the 9-lipoxygenase pathway in elicitor-treated potato cells. J. Biol. Chem. 276:6267-6273.

Göbel, C., Feussner, I., Hamberg, M., and Rosahl, S. 2002. Oxylipin profiling in pathogen-infected potato leaves. Biochim. Biophys. Acta 1584:55-64.

Göbel, C., Feussner, I., and Rosahl, S. 2003. Lipid peroxidation during the hypersensitive response in potato in the absence of 9-lipoxygenases. $\mathrm{J}$. Biol. Chem. 278:52834-52840.

Görlach, J., Volrath, S., Knauf-Beiter, G., Hengy, G., Beckhove, U., Kogel, K. H., Oostendorp, M., Staub, T., Ward, E., Kessmann, H., and Ryals, J 1996. Benzothiadiazole, a novel class of inducers of systemic acquired resistance, activates gene expression and disease resistance in wheat. Plant Cell 8:629-643.

Haas, B. J., Kamoun, S., Zody, M. C., Jiang, R. H., Handsaker, R. E., Cano, L. M., Grabherr, M., Kodira, C. D., Raffaele, S., Torto-Alalibo, T., Bozkurt, T. O., Ah-Fong, A. M., Alvarado, L., Anderson, V. L., Armstrong, M. R., Avrova, A., Baxter, L., Beynon, J., Boevink, P. C., Bollmann, S. R., Bos, J. I., Bulone, V., Cai, G., Cakir, C., Carrington, J. C., Chawner, M., Conti, L., Costanzo, S., Ewan, R., Fahlgren, N., Fischbach, M. A., Fugelstad, J., Gilroy, E. M., Gnerre, S., Green, P. J., Grenville-Briggs, L. J., Griffith, J., Grünwald, N. J., Horn, K., Horner, N. R., Hu, C. H., Huitema, E., Jeong, D. H., Jones, A. M., Jones, J. D., Jones, R. W., Karlsson, E. K., Kunjeti, S. G., Lamour, K., Liu, Z., Ma, L., Maclean, D., Chibucos, M. C., McDonald, H., McWalters, J., Meijer, H. J., Morgan, W., Morris, P. F., Munro, C. A., O’Neill, K., Ospina-Giraldo, M., Pinzón, A., Pritchard, L., Ramsahoye, B., Ren, Q., Restrepo, S., Roy, S., Sadanandom, A., Savidor, A., Schornack, S., Schwartz, D. C., Schumann, U. D., Schwessinger, B., Seyer, L., Sharpe, T., Silvar, C., Song, J., Studholme, D. J., Sykes, S., Thines, M., van de Vondervoort, P. J., Phuntumart, V., Wawra, S., Weide, R., Win, J., Young, C., Zhou, S., Fry, W., Meyers, B. C., van West, P., Ristaino, J., Govers, F., Birch, P. R., Whisson, S. C., Judelson, H. S., and Nusbaum, C. 2009. Genome sequence and analysis of the Irish potato famine pathogen Phytophthora infestans. Nature 461:393-398.

Halim, V. A., Hunger, A., Macioszek, V., Landgraf, P., Nürnberger, T., Scheel, D., and Rosahl, S. 2004. The oligopeptide elicitor Pep-13 induces salicylic acid-dependent and -independent defense reactions in potato. Physiol. Mol. Plant P. 64:311-318.

Halim, V. A., Eschen-Lippold, L., Altmann, S., Birschwilks, M., Scheel, D., and Rosahl, S. 2007. Salicylic acid is important for basal defense of Solanum tuberosum against Phytophthora infestans. Mol. PlantMicrobe Interact. 20:1346-1352.

Halim, V. A., Altmann, S., Ellinger, D., Eschen-Lippold, L., Miersch, O., Scheel, D., and Rosahl, S. 2009. PAMP-induced defense responses in potato require both salicylic acid and jasmonic acid. Plant J. 57:230242.

Hamiduzzaman, M. Md., Jakab, G., Barnavon, L., Neuhaus, J.-M., and Mauch-Mani, B. 2005. $\beta$-Aminobutyric acid-induced resistance against downy mildew in grapevine acts through the potentiation of callose formation and jasmonic acid signaling. Mol. Plant-Microbe Interact. 18:819-829.

Howe, G. A., Lightner, J., Browse, J., and Ryan, C. A. 1996. An octadecanoid pathway mutant (JL5) of tomato is compromised in signaling for defense against insect attack. Plant Cell 8:2067-2077.

Hwang, B. K., Sunwoo, J. Y., Kim, Y. J., and Kim, B. S. 1997. Accumulation of beta-1,3-glucanase and chitinase isoforms, and salicylic acid in the DL-beta-amino-n-butyric acid-induced resistance response of pepper stems to Phytophthora capsici. Physiol. Mol. Plant P. 51:305-322.

Isakeit, T., Gao, X., and Kolomiets, M. 2007. Increased resistance of a maize mutant lacking the 9-lipoxygenase gene, $Z m L O X 3$, to root rot caused by Exserohilum pedicellatum. J. Phytopathol. 155:758-760.

Jakab, G., Cottier, V., Toquin, V., Rigoli, G., Zimmerli, L., Métraux, J. P., and Mauch-Mani, B. 2001. beta-Aminobutyric acid-induced resistance in plants. Eur. J. Plant Pathol. 107:29-37.

Jeun, Y. C., Siegrist, J., and Buchenauer, H. 2000. Biochemical and cytological studies on mechanisms of systemically induced resistance to Phytophthora infestans in tomato plants. J. Phytopathol. 148:129-140.

Jung, H. W., Tschaplinski, T. J., Wang, L., Glazebrook, J., and Greenberg, J. T. 2009. Priming in systemic plant immunity. Science 324:89-91.

Kamoun, S. 2003. Molecular genetics of pathogenic oomycetes. Eukaryot. Cell 2:191-199. 
Kim, H. J., and Jeun, Y. C. 2007. Infection structures on the infected leaves of potato pre-inoculated with bacterial strains and DL-3-amino butyric acid after challenge inoculation with Phytophthora infestans. Plant Pathol. J. 23:203-209.

Kombrink, E., Büchter, R., Wegener, S., and Scheel, D. 1996. In: Modern Fungicides and Antifungal Compounds. Proc. Int. Symp., 11th. H. Lyr, P. E. Russell, and H. D. Sisler, eds. Intercept, Andover, England.

Li, Y., Tian, Z., Liu, J., and Xie, C. 2009. Comparative cDNA-AFLP analysis reveals that DL-beta-amino-butyric acid induces resistance through early activation of the host-defense genes in potato. Physiol. Plant 136:19-29.

Loake, G., and Grant, M. 2007. Salicylic acid in plant defence-the players and protagonists. Curr. Opin. Plant Biol. 10:466-472.

Maldonado, A. M., Doerner, P., Dixon, R. A., Lamb, C. J., and Cameron, R. K. 2002. A putative lipid transfer protein involved in systemic resistance signalling in Arabidopsis. Nature 419:399-403.

Marmey, P., Jalloul, A., Alhamdia, M., Assigbetse, K., Cacas, J. L., Voloudakis, A. E., Champion, A., Clerivet, A., Montillet, J. L., and Nicole, M. 2007. The 9-lipoxygenase GhLOX1 gene is associated with the hypersensitive reaction of cotton Gossypium hirsutum to Xanthomonas campestris pv malvacearum. Plant Physiol. Bioch. 45:596-606.

Mita, G., Fasano, P., De Domenico, S., Perrone, G., Epifani, F., Iannacone, R., and Santino, A. 2007. 9-Lipoxygenase metabolism is involved in the almond/Aspergillus carbonarius interaction. J. Exp. Bot. 58:1803-1811.

Oh, S. K., Young, C., Lee, M., Oliva, R., Bozkurt, T. O., Cano, L. M., Win, J., Bos, J. I., Liu, H. Y., van Damme, M., Morgan, W., Choi, D., Van der Vossen, E. A., Vleeshouwers, V. G., and Kamoun, S. 2009. In planta expression screens of Phytophthora infestans RXLR effectors reveal diverse phenotypes, including activation of the Solanum bulbocastanum disease resistance protein Rpi-blb2. Plant Cell 21:2928-2947.

Olivieri, F. P., Lobato, M. C., Altamiranda, E., Daleo, G. R., Huarte, M., Guevara, M. G., and Andreu, A. B. 2009. BABA effects on the behaviour of potato cultivars infected by Phytophthora infestans and Fusarium solani. Eur. J. Plant Pathol. 123:47-56.

Park, T. H., Vleeshouwers, V., Jacobsen, E., van der Vossen, E., and Visser, R. G. F. 2009. Molecular breeding for resistance to Phytophthora infestans (Mont.) de Bary in potato (Solanum tuberosum L.): A perspective of cisgenesis. Plant Breed. 128:109-117.

Pieterse, C. M. J., van Wees, S. C. M., van Pelt, J. A., Knoester, M., Laan, R., Gerrits, N., Weisbeek, P. J., and van Loon, L. C. 1998. A novel signaling pathway controlling induced systemic resistance in Arabidopsis. Plant Cell 10:1571-1580.

Pieterse, C. M. J., Van Pelt, J. A., Van Wees, S. C. M., Ton, J., LeonKloosterziel, K. M., Keurentjes, J. J. B., Verhagen, B. W. M., Knoester, M., Van der Sluis, I., Bakker, P. A. H. M., and Van Loon, L. C. 2001. Rhizobacteria-mediated induced systemic resistance: Triggering, signalling and expression. Eur. J. Plant Pathol. 107:51-61.

Prost, I., Dhondt, S., Rothe, G., Vicente, J., Rodriguez, M. J., Kift, N., Carbonne, F., Griffiths, G., Esquerré-Tugayé, M. T., Rosahl, S., Castresana, C., Hamberg, M., and Fournier, J. 2005. Evaluation of the antimicrobial activities of plant oxylipins supports their involvement in defense against pathogens. Plant Physiol. 139:1902-1913.

Rancé, I., Fournier, J., and Esquerré-Tugayé, M. T. 1998. The incompatible interaction between Phytophthora parasitica var. nicotianae race 0 and tobacco is suppressed in transgenic plants expressing antisense lipoxygenase sequences. Proc. Natl. Acad. Sci. U.S.A. 95:6554-6559.

Rosahl, S., and Feussner, I. 2004. Oxylipins. Pages 329-354 in: Plant Lipids: Biology, Utilisation and Manipulation. D. J. Murphy, ed. Blackwell Publisher, Oxford.
Royo, J., Vancanneyt, G., Perez, A. G., Sanz, C., Stormann, K., Rosahl, S., and SanchezSerrano, J. J. 1996. Characterization of three potato lipoxygenases with distinct enzymatic activities and different organ-specific and wound-regulated expression patterns. J. Biol. Chem. 271:2101221019.

Sagaram, U. S., Kolomiets, M., and Shim, W.-B. 2006. Regulation of fumonisin biosynthesis in Fusarium verticillioides-maize system. Plant Pathol. J. 22:203-210.

Si-Ammour, A., Mauch-Mani, B., and Mauch, F. 2003. Quantification of induced resistance against Phytophthora species expressing GFP as a vital marker: Beta-aminobutyric acid but not BTH protects potato and Arabidopsis from infection. Mol. Plant Pathol. 4:237-248.

Siegrist, J., Orober, M., and Buchenauer, H. 2000. beta-aminobutyric acidmediated enhancement of resistance in tobacco to tobacco mosaic virus depends on the accumulation of salicylic acid. Physiol. Mol. Plant P. 56:95-106.

Ton, J., and Mauch-Mani, B. 2004. beta-amino-butyric acid-induced resistance against necrotrophic pathogens is based on ABA-dependent priming for callose. Plant J. 38:119-130.

Turner, R.S. 2005. After the famine: Plant pathology, Phytophthora infestans, and the late blight of potatoes, 1845-1960. Hist. Stud. Phys. Biol. Sci. 35:341-370.

van Poppel, P. M. J. A., Guo, J., de Vondervoort, P. J. I., Jung, M. W. M., Birch, P. R. J., Whisson, S. C., and Govers, F. 2008. The Phytophthora infestans avirulence gene Avr4 Encodes an RXLR-dEER effector. Mol. Plant-Microbe Interact. 21:1460-1470.

Verberne, M. C., Brouwer, N., Delbianco, F., Linthorst, H. J., Bol, J. F., and Verpoorte, R. 2002. Method for the extraction of the volatile compound salicylic acid from tobacco leaf material. Phytochem. Anal. 13:45-50.

Vernooij, B., Friedrich, L., Goy, P. A., Staub, T., Kessmann, H., and Ryals, J. 1995. 2,6-Dichloroisonicotinic acid-induced resistance to pathogens without the accumulation of salicylic acid. Mol. Plant-Microbe Interact. $8: 228-234$

Ward, E. R., Uknes, S.J., Williams, S.C., Dincher, S. S., Wiederhold, D. L., Alexander, D. C., Ahl-Goy, P., Métraux, J. P., and Ryals, J. A. 1991. Coordinate gene activity in response to agents that induce systemic acquired resistance. Plant Cell 3:1085-1094.

Wasternack, C. 2007. Jasmonates: An update on biosynthesis, signal transduction and action in plant stress response, growth and development. Ann. Bot. London 100:681-697.

Weber, H., Chetelat, A., Caldelari, D., and Farmer, E. E. 1999. Divinyl ether fatty acid synthesis in late blight-diseased potato leaves. Plant Cell 11:485-493.

Yan, Z., Reddy, M. S., Ryu, C. M., McInroy, J. A., Wilson, M., and Kloepper, J. W. 2002. Induced systemic protection against tomato late blight elicited by plant growth-promoting rhizobacteria. Phytopathology 92:1329-1333.

Zimmerli, L., Métraux, J. P., and Mauch-Mani, B. 2001. beta-aminobutyric acid-induced protection of Arabidopsis against the necrotrophic fungus Botrytis cinerea. Plant Physiol. 126:517-523.

Zimmerli, L., Jakab, C., Métraux, J. P., and Mauch-Mani, B. 2000. Potentiation of pathogen-specific defense mechanisms in Arabidopsis by beta-aminobutyric acid. Proc. Natl. Acad. Sci. U.S.A. 97:12920-12925.

\section{AUTHOR-RECOMMENDED INTERNET RESOURCE}

United Nations Food and Agriculture Organization website: www.fao.org 